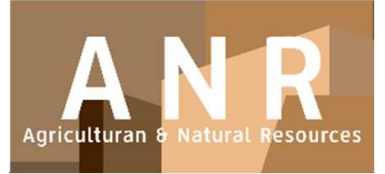

PAPER - OPEN ACCESS

\title{
Peran Jasa Ekosistem Dalam Meningkatkan Kinerja Sektor Kehutanan Kabupaten Merangin
}

\author{
Author : : Omo Rusdiana dkk., \\ DOI $\quad: 10.32734 /$ anr.v3i1.836 \\ Electronic ISSN : :2654-7023 \\ Print ISSN : $2654-7015$
}

Volume 3 Issue 1 - 2020 TALENTA Conference Series: Agriculturan \& Natural Resource (ANR)

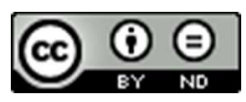

This work is licensed under a Creative Commons Attribution-NoDerivatives 4.0 International License.

Published under licence by TALENTA Publisher, Universitas Sumatera Utara

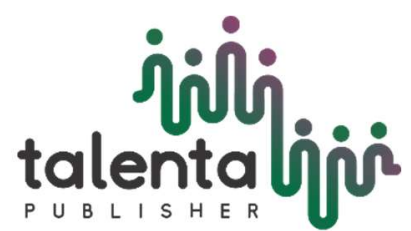




\title{
jibli (4) TALENTA Conference Series
}

Available online at https://talentaconfseries.usu.ac.id/anr

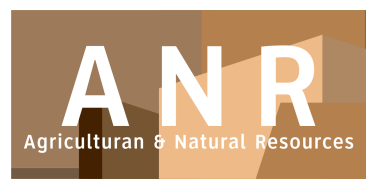

\section{Peran Jasa Ekosistem Dalam Meningkatkan Kinerja Sektor Kehutanan Kabupaten Merangin}

\author{
Omo Rusdiana ${ }^{\mathrm{a}, \mathrm{b}, *}$, Mia Ermyanyla ${ }^{\mathrm{b}}$, Nana Rusyana ${ }^{\mathrm{b}, \mathrm{c}}$ \\ ${ }^{a}$ Departemen Silvikultur, Fakultas Kehutanan, Institut Pertanian Bogor. Kampus IPB Darmaga Divisi Ekologi Hutan, Departemen Silvikultur, \\ Fakultas Kehutanan, Institut Pertanian Bogor, Bogor 16680, Indonesia \\ ${ }^{b}$ Pusat Pengkajian Perencanaan dan Pengembangan Wilayah (P4W), Lembaga Penelitian dan Pengabdian kepada Masyarakat (LPPM), Institut \\ Pertanian Bogor, Kampus IPB Baranangsiang, Jl. Pajajaran, Bogor 16144, Indonesia \\ ${ }^{c}$ Program Magister Ilmu Perencanaan Wilayah (PWL), Sekolah Pascasarjana, Institut Pertanian Bogor. Kampus IPB Darmaga Jl. Meranti, \\ Bogor 16680, Indonesia \\ orusdiana@gmail.com
}

\begin{abstract}
Abstrak
Luas wilayah Kabupaten Merangin adalah 767.890 ha, dengan 45,27\% tutupan lahannya berupa kawasan hutan. Kawasan hutan didominasi oleh hutan konservasi (45,52\% dari luas kawasan hutan), selanjutnya hutan produksi (43,35\%), dan hutan lindung $(11,13 \%)$. Ekosistem kawasan hutan jika dikelola dengan baik akan memberikan banyak manfaat bagi lingkungan dan kesejahteraan masyarakat. Namun hingga saat ini, laju deforestasi akibat alih fungsi hutan, penebangan liar, dan penambangan liar semakin meningkat. Hal ini telah memicu berbagai masalah ekologis di Kabupaten Merangin. Dari sisi ekonomi, sektor pertanian yang terdiri dari sub sektor pertanian, peternakan, perikanan dan kehutanan memberikan kontribusi terbesar terhadap ekonomi daerah pada tahun 2017 dibandingkan dengan sektor lainnya, yaitu sebesar 49,09\%. Namun, jika dilihat berdasarkan kontribusi antar sub sektor, kontribusi sub sektor kehutanan terhadap sektor pertanian hanya sebesar 2,66\%. Nilai ini tidak sebanding dengan luasan kawasan hutan, terutama hutan produksi yang ada. Munculnya masalah ekologis dan rendahnya kontribusi sektor kehutanan menunjukkan pengelolaan kawasan hutan belum berjalan dengan baik. Berdasarkan pemasalahan tersebut penelitian ini dilakukan dengan tujuan untuk mengidentifikasi jasa-jasa ekosistem hutan berdasarkan fungsinya, menganalisis peran jasa ekosistem hutan terhadap nilai ekologi, dan sosial-ekonomi masyarakat, serta merumuskan kebijakan pengelolaan hutan berbasis jasa ekosistem dalam rangka meningkatkan kinerja sektor kehutanan Kabupaten Merangin. Metode analisis yang digunakan meliputi kajian literatur, analisis spasial, analisis sosial-ekonomi kehutanan dengan pendekatan statistika deskriptif, serta analisis kebijakan dengan pendekatan SWOT (Strengths, Weaknesss, Opportunities, and Threats). Integrasi jasa ekosistem dalam pengelolaan kawasan hutan merupakan salah satu kebijakan yang dapat meningkatkan kinerja sektor kehutanan, baik dari aspek ekologis, maupun sosialekonomi secara berkelanjutan.
\end{abstract}

Kata Kunci: Berkelanjutan; integrasi; jasa ekosistem; kinerja

\section{Pendahuluan}

Kabupaten Merangin merupakan kabupaten yang secara administratif terdiri dari 24 kecamatan, dengan ibukota Bangko. Berdasarkan data dari Badan Pusat Statistik [1], luas wilayah Kabupaten Merangin adalah 767.890 ha. Jumlah penduduk Kabupaten Merangin tahun 2017 adalah 377.905 jiwa. Terkait tutupan lahan [2], diketahui bahwa 45,27\% dari luas wilayah Kabupaten Merangin atau seluas 347.602 ha merupakan kawasan hutan, dan sisanya merupakan kawasan non hutan (perkebunan, tambang, permukiman, dan lain-lain). Jika dilihat berdasarkan fungsi 
kawasan hutan, kawasan hutan dominan merupakan hutan konservasi yaitu 45,52\% dari total kawasan hutan (158.239 ha), selanjutnya adalah hutan produksi (43,35\% dari total kawasan hutan), dan hutan lindung (11,13\% dari total kawasan hutan).

Hutan dengan segala fungsinya, baik dari aspek sosial-ekonomi maupun ekologis, memberikan peran yang sangat penting dalam proses pembangunan suatu daerah. Dari aspek sosial-ekonomi, kawasan hutan, terutama hutan produksi, menjadi modal untuk menopang perekonomian daerah dan kesejahteraan masyarakat. Dari aspek ekologis, kawasan hutan memiliki peran selain untuk mempertahankan fungsi hutan itu sendiri, juga sebagai penyedia jasa ekosistem untuk keamanan dan keberlanjutan lingkungan hidup. Kontribusi sektor kehutanan, terutama hutan produksi, bagi perekonomian di antaranya adalah sebagai penyumbang devisa, penyedia bahan baku industri, penyedia lapangan kerja, serta peningkatan pendapatan daerah dan kesejahteraan masyarakat.

Fenomena yang terjadi di Kabupaten Merangin saat ini adalah kawasan hutan mendapat tekanan dari berbagai ancaman dan gangguan yang mengarah pada pengrusakan hutan. Ancaman tersebut berupa deforestasi yang disebabkan oleh semakin meningkatnya lahan terganggu atau lahan kritis, penebangan kayu liar (illegal logging) yang tidak terkendali, dan juga penambangan liar (illegal mining). Hal ini menunjukkan bahwa pemanfaatan dan pengelolaan hutan di Kabupaten Merangin saat ini cenderung mengedepankan aspek ekonomi yang pada akhirnya mempengaruhi kinerja jasa ekosistem lainnya (seperti penyerapan karbon, pengaturan air, pengaturan iklim, dan sebagainya). Jika hal ini terus terjadi, maka dapat menyebabkan kualitas dan kuantitas jasa-jasa ekosistem hutan cenderung menurun dari waktu ke waktu dan pada akhirnya akan menyebabkan penurunan produktivitas dan meningkatkan kerusakan atau degradasi hutan. Peningkatan degradasi hutan merupakan kekhawatiran besar bagi keberlanjutan kawasan hutan. Kehilangan jasa ekosistem hutan akan mengurangi kesejahteraan manusia di semua tingkatan. Guna mengantisipasi hal ini, maka diperlukan pengelolaan kawasan hutan berbasis jasa ekosistem yang terintegrasi dengan baik sehingga kelestarian atau keberlanjutan hutan dapat terjaga dan dapat memberikan manfaat yang optimal bagi lingkungan hidup serta kesejahteraan masyarakat.

Berdasarkan potensi dan permasalahan di atas, maka penelitian ini dilakukan dengan tujuan untuk: (1) mengidentifikasi jasa-jasa ekosistem hutan; (2) menganalisis peran jasa ekosistem hutan dari aspek ekologis dan sosial-ekonomi; dan (3) merumuskan kebijakan dan strategi pengelolaan kawasan hutan yang berkelanjutan di Kabupaten Merangin.

\section{Metode Penelitian}

Data yang digunakan dalam penelitian ini hanya data sekunder, yang terdiri dari data statistik, peta, berbagai laporan kajian, literatur, dan regulasi/kebijakan terkait. Analisis yang digunakan dalam penelitian ini mencakup: (1) analisis/kajian literatur untuk mengidentifikasi jasa-jasa ekosistem yang tersemat dalam kawasan hutan; (2) analisis kinerja kehutanan untuk mengetahui peran jasa ekosistem hutan dari aspek ekologis (daya dukung) dan sosialekonomi dengan menggunakan analisis spasial dan analisis statistika deskriptif; dan (3) analisis kebijakan dengan menggunakan pendekatan SWOT (Strengths, Weaknesss, Opportunities, and Threats) untuk merumuskan kebijakan dan strategi pengelolaan kawasan hutan berbasis jasa ekosistem yang terintegrasi dan berkelanjutan.

\section{Hasil dan Pembahasan}

\subsection{Jasa-jasa Ekosistem Kawasan Hutan}

Ekosistem hutan memberikan berbagai manfaat jasa ekosistem bagi keberlangsungan lingkungan hidup dan kesejahteraan manusia. Menurut [3], klasifikasi jasa ekosistem tergolong dalam empat kategori utama, yaitu berupa jasa penyedia (provisioning services), jasa pengaturan (regulating services), jasa pendukung (supporting services), dan jasa kebudayaan (cultural services). Jasa ekosistem kawasan hutan sebagai jasa penyedia mencakup penyediaan jasa seperti pangan, serat, energi, sumberdaya genetik, dan lainnya. Jasa ekosistem yang kedua adalah jasa pengaturan, yaitu fungsi kawasan hutan produksi untuk menjaga kualitas udara, pengaturan iklim, pengaturan tata aliran air, dan lainnya. Jasa ekosistem yang ketiga adalah jasa pendukung yang bertujuan untuk mendukung keberlangsungan ekosistem hutan, seperti siklus hara, penjaga kesuburan tanah, keragaman hayati, dan lainnya. Jasa ekosistem yang 
keempat adalah jasa kebudayaan. Jasa kebudayaan yang tersemat dalam kawasan hutan contohnya adalah rekreasi, ekowisata, dan estetika. Hasil identifikasi berbagai jenis jasa ekosistem yang tersemat dalam kawasan hutan berdasarkan empat kategori tersebut disajikan pada Gambar 1.

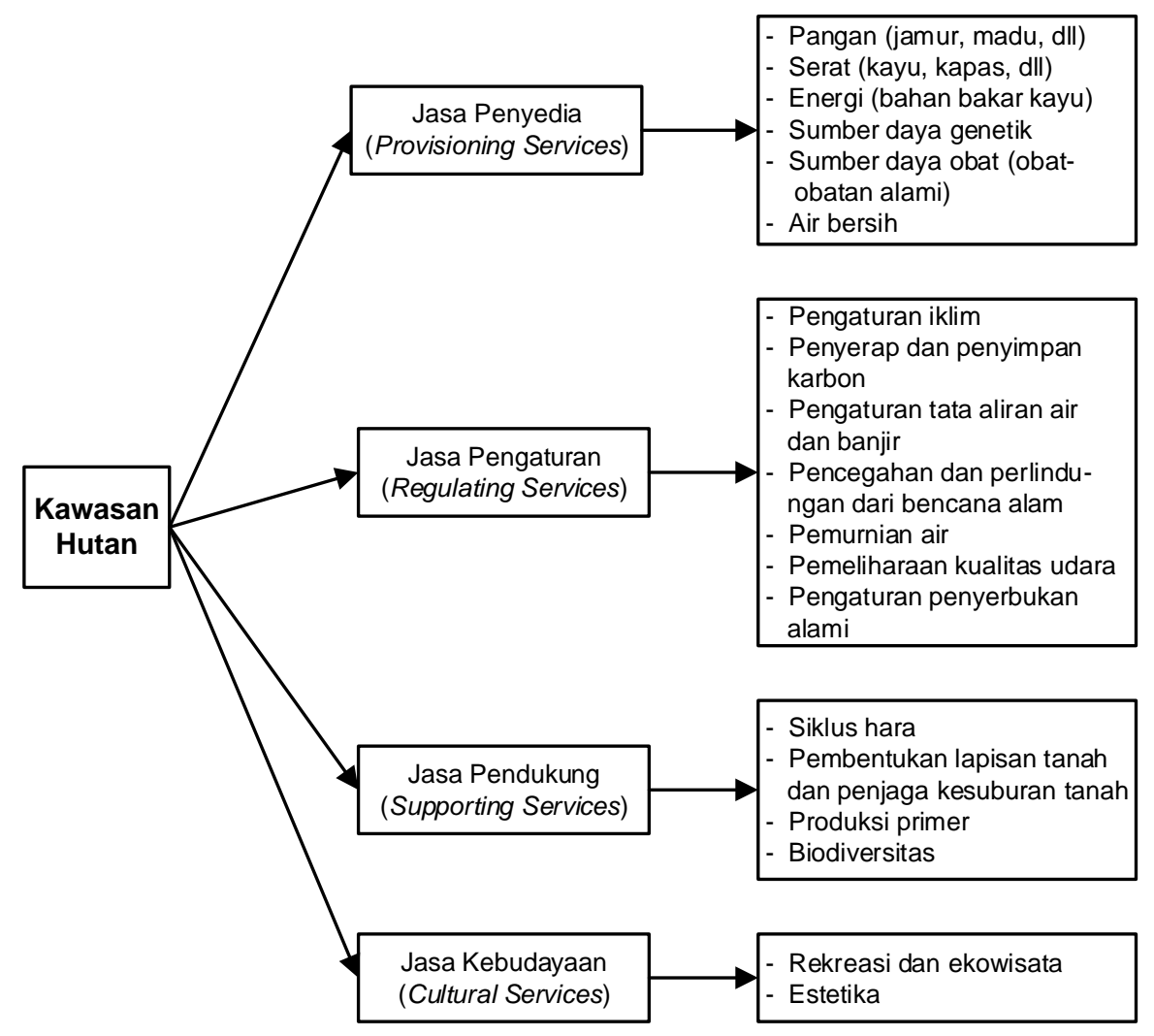

Gambar 1. Jasa-jasa ekosistem yang tersemat dalam kawasan hutan

\subsection{Daya Dukung Kawasan Hutan Berdasarkan Jenis Jasa Ekosistem}

Daya dukung lingkungan hidup merupakan kemampuan lingkungan hidup untuk dapat mendukung perikehidupan manusia, mahluk hidup lain, dan keseimbangan antar keduanya [4]. Daya dukung lahan untuk kawasan hutan ditetapkan berdasarkan fungsi dan kemampuan lahannya. Penetapan kawasan ini didasarkan pada kemampuannya atau kapasitasnya dalam mendukung aktivitas manusia tanpa menimbulkan kerusakan lingkungan. Sehubungan dengan keterbatasan data yang tersedia, daya dukung kawasan hutan tidak dianalisis berdasarkan semua jasa ekosistem yang telah teridentifikasi pada uraian sebelumnya. Data daya dukung kawasan hutan yang tersedia dan dianalisis lebih lanjut dalam penelitian ini adalah daya dukung dari tujuh jasa ekosistem, yaitu jasa ekosistem hutan sebagai penyedia pangan, penyedia energi, penyedia air bersih, penyedia sumber daya genetik, pengaturan iklim, pengaturan tata air, dan pengaturan mitigasi bencana. Hasil analisis daya dukung ketujuh jasa ekosistem hutan tersebut dikelompokkan ke dalam tiga kategori, yaitu daya dukung tinggi, sedang, dan rendah. Peta sebaran tingkat daya dukung kawasan hutan dan penggunaan lainnya di Kabupaten Merangin secara spasial berdasarkan jasa ekosistem yang dianalisis disajikan pada Gambar 2 dan Gambar 3. 

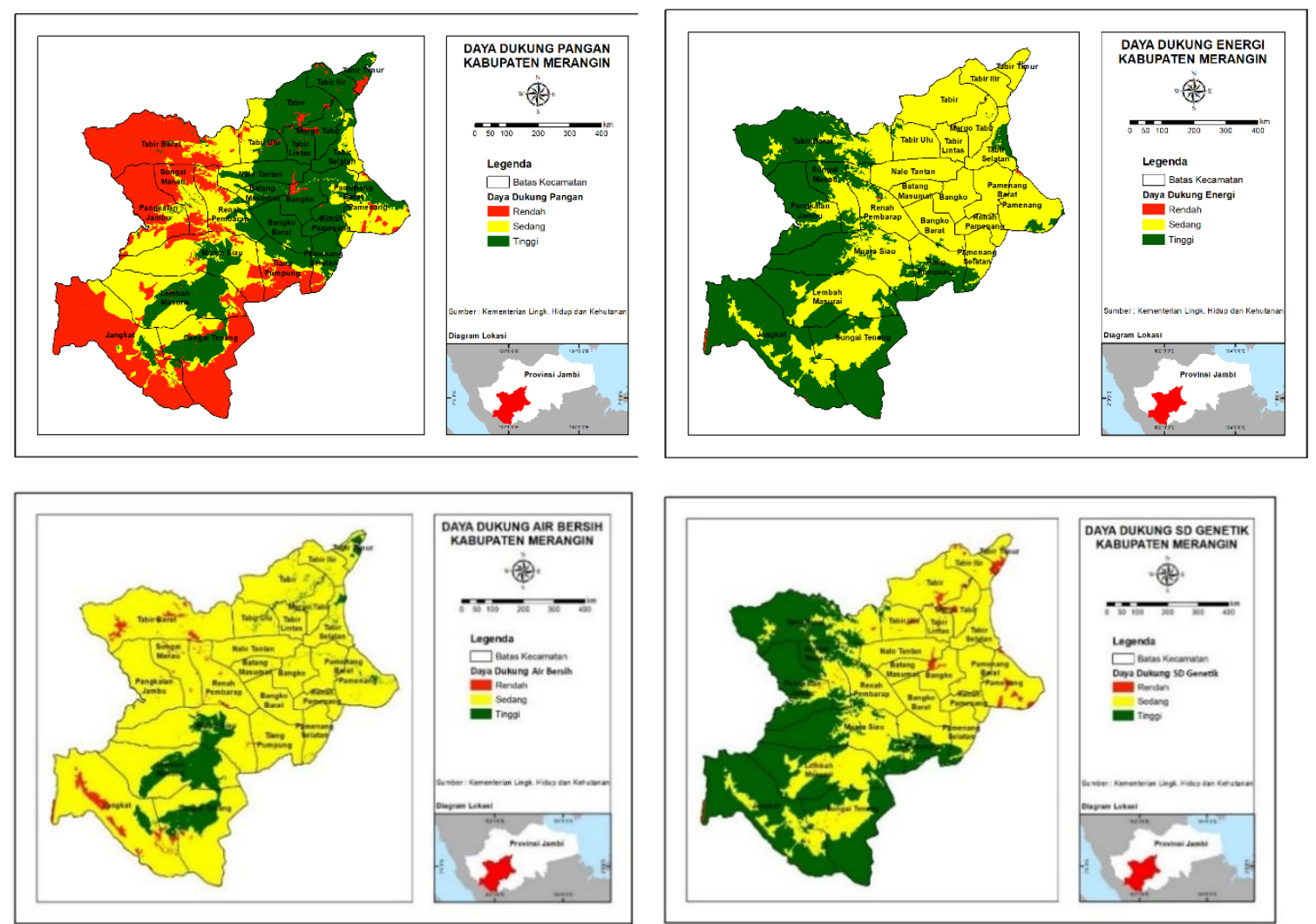

Gambar 2. Daya dukung kawasan hutan dan penggunaan lainnya di Kabupaten Merangin berdasarkan jasa ekosistem: penyedia pangan, energi, air bersih, dan sumber daya genetik
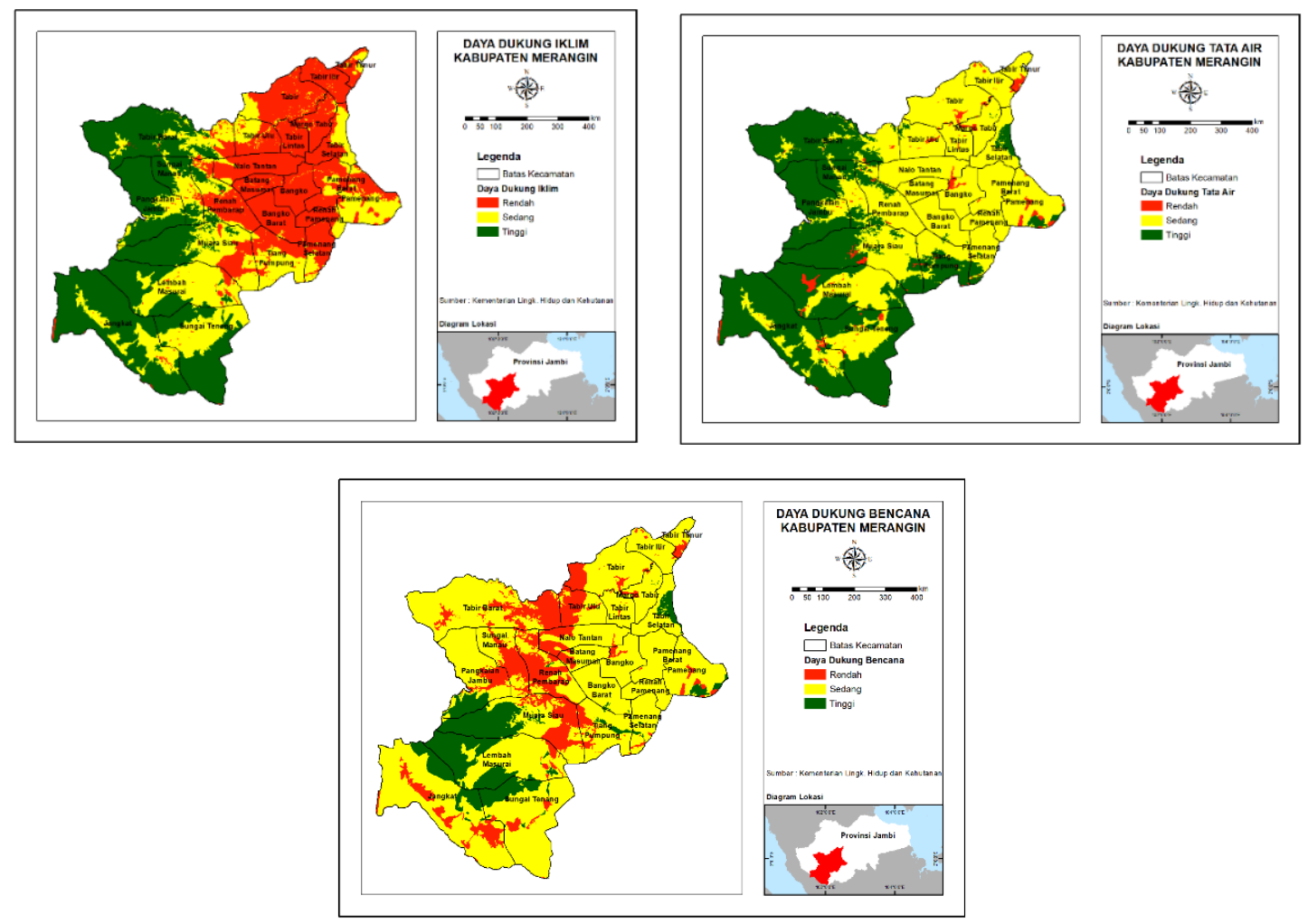
Gambar 3. Daya dukung kawasan hutan dan penggunaan lainnya di Kabupaten Merangin berdasarkan jasa ekosistem: pengaturan iklim, tata air, dan mitigasi bencana

Pada kawasan hutan konservasi, hasil analisis spasial menunjukkan bahwa daya dukung kawasan hutan konservasi di Kabupaten Merangin sebagai penyedia pangan dominan termasuk dalam kategori rendah $(67,12 \%)$, penyedia energi dominan tinggi $(95,04 \%)$, penyedia air bersih dominan sedang $(96,35 \%)$, penyedia sumber daya genetik dominan tinggi $(95,28 \%)$, pengaturan iklim dominan tinggi $(94,20 \%)$, pengaturan tata air dominan tinggi $(95,17 \%)$, dan pengaturan mitigasi bencana dominan sedang $(64,27 \%)$. Pada kawasan hutan produksi, daya dukung sebagai penyedia pangan dominan termasuk dalam kategori rendah (50,03\%), penyedia energi dominan tinggi $(64,78 \%)$, penyedia air bersih dominan sedang $(91,69 \%)$, penyedia sumber daya genetik dominan tinggi $(65,20 \%)$, pengaturan iklim dominan tinggi $(55,94 \%)$, pengaturan tata air dominan tinggi $(66,80 \%)$, dan pengaturan mitigasi bencana dominan sedang $(59,31 \%)$.

Pada kawasan hutan lindung, daya dukung hutan lindung sebagai penyedia pangan dominan termasuk dalam kategori rendah $(82,24 \%)$, penyedia energi dominan tinggi $(86,49 \%)$, penyedia air bersih dominan sedang $(97,54 \%)$, penyedia sumber daya genetik dominan tinggi $(86,49 \%)$, pengaturan iklim dominan sedang $(55,17 \%)$, pengaturan tata air dominan tinggi (86,53\%), dan pengaturan mitigasi bencana dominan sedang $(82,02 \%)$. Secara agregat, daya dukung kawasan hutan di Kabupaten Merangin sebagai penyedia pangan dominan termasuk dalam kategori rendah $(61,42 \%)$, penyedia energi dominan tinggi $(81,07 \%)$, penyedia air bersih dominan sedang $(94,47 \%)$, penyedia sumber daya genetik dominan tinggi $(81,36 \%)$, pengaturan iklim dominan tinggi $(71,30 \%)$, pengaturan tata air dominan tinggi $(82,01 \%)$, dan pengaturan mitigasi bencana dominan sedang $(64,08 \%)$. Hal ini menunjukkan bahwa pada umumnya daya dukung kawasan hutan di Kabupaten Merangin berdasarkan ketujuh jasa ekosistem hutan yang dianalisis berada dalam kondisi baik pada kisaran kategori daya dukung sedang-tinggi.

\subsection{Kontribusi Sektor Kehutanan terhadap Perekonomian Daerah}

Pada uraian sebelumnya telah disampaikan bahwa kawasan hutan mendominasi tutupan lahan di Kabupaten Merangin, yaitu 45,27\% dari total luas wilayah. Pada Gambar 2 dan Gambar 3 juga dapat dilihat bahwa kondisi daya dukung kawasan hutan di Kabupaten Merangin berdasarkan jasa-jasa ekosistem yang tersemat di dalamnya relatif baik. Namun kondisi ini tidak selaras jika dilihat dari sisi ekonomi. Kontribusi sektor kehutanan terhadap perekonomian daerah Kabupaten Merangin relatif kecil dibandingkan dengan sektor lainnya. Produk Dosmestik Regional Bruto (PDRB) merupakan salah satu indikator yang dapat menggambarkan tingkat perekonomian suatu daerah. Tabel 1 menyajikan nilai PDRB Kabupaten Merangin atas dasar harga konstan Tahun 2010 menurut lapangan usaha atau sektor tahun 2015-2017. Berdasarkan data pada tabel tersebut, dapat dilihat bahwa nilai PDRB Kabupaten Merangin dalam kurun tahun 2015-2017 mengalami peningkatan, begitu juga dengan nilai PDRB sub sektor kehutanan walau peningkatannya tidak signifikan. Nilai PDRB Kabupaten Merangin tahun 2017 sebesar 8.961 miliar rupiah. Jika dilihat berdasarkan sektor, nilai PDRB sektor pertanian yang terdiri dari sub sektor pertanian, peternakan, perikanan dan kehutanan pada tahun 2017 adalah sebesar 4.399 miliar rupiah. Nilai PDRB sektor ini adalah yang tertinggi dibandingkan nilai PDRB sektor lainnya. Namun, jika dilihat lebih rinci, nilai PDRB sub sektor kehutanan pada tahun 2017 hanya 117 miliar rupiah. Nilai PDRB sub sektor kehutanan ini relatif kecil dibandingkan nilai PDRB sub sektor lainnya dalam sektor pertanian.

Tabel 1. Produk Domestik Regional Bruto (PDRB) Kabupaten Merangin Atas Dasar Harga Konstan (ADHK) Tahun 2010 Menurut Lapangan Usaha/Sektor Tahun 2015-2017

\begin{tabular}{lllll}
\hline \multirow{2}{*}{ No } & Lapangan Usaha & \multicolumn{3}{l}{ PDRB ADHB (Juta Rupiah) } \\
\cline { 3 - 5 } & & 2015 & 2016 & 2017 \\
\hline 1 & Pertanian & 3.956 .446 & 4.189 .648 & 4.399 .224 \\
\cline { 2 - 5 } & - Tanaman Tanaman Pangan & 258.673 & 280.373 & 292.050 \\
\cline { 2 - 5 } & - Tanaman Hortikultura & 319.387 & 344.384 & 370.645 \\
\cline { 2 - 5 } & - Tanaman Perkebunan & 3.118 .239 & 3.294 .814 & 3.452 .477 \\
\hline
\end{tabular}




\begin{tabular}{lllll}
\hline & - Peternakan & 103.830 & 107.739 & 114.410 \\
\cline { 2 - 5 } & - Jasa Pertanian dan Perburuan & 13.152 & 13.739 & 14.347 \\
\cline { 2 - 5 } & - Kehutanan dan Penebangan Kayu & 107.415 & 111.677 & 117.034 \\
\cline { 2 - 5 } & - Perikanan & 35.749 & 36.922 & 38.262 \\
\hline 2 & Pertambangan dan Penggalian & 186.698 & 195.004 & 204.128 \\
\hline 3 & Industri Pengolahan & 622.827 & 660.312 & 695.164 \\
\hline 5 & Listrik dan Air Minum & 19.842 & 21.094 & 21.481 \\
\hline 6 & Bangunan & 582.437 & 615.822 & 649.737 \\
\hline 7 & Perdagangan, Hotel dan Restoran & 993.594 & 1.077 .146 & 1.169 .514 \\
\hline 8 & Lemgangkutan dan Komunikasi & 493.768 & 530.522 & 573.683 \\
\hline 9 & Jasa-jasa & 320.872 & 331.933 & 348.681 \\
\hline & TOTAL PDRB (9 Sektor) & 816.516 & 868.219 & 899.611 \\
\hline
\end{tabular}

Sumber: BPS (2018)

Tabel 2 menunjukkan tingkat kontribusi antar sektor terhadap PDRB Kabupaten Merangin. Berdasarkan data pada tabel tersebut, dapat dilihat bahwa sektor pertanian memberikan kontribusi terbesar terhadap PDRB Kabupaten Merangin dibandingkan dengan sektor lainnya. Pada tahun 2017, sektor pertanian memberikan kontribusi sebesar 49,09\% terhadap PDRB. Namun jika dilihat lebih rinci menurut sub sektor dalam sektor pertanian (pada Tabel 3), ternyata sub sektor kehutanan pada tahun 2017 hanya memberikan kontribusi sebesar 2,66\% terhadap PDRB sektor pertanian dan cenderung menurun dalam kurun tahun 2015-2017. Hal ini sangat disayangkan, mengingat penutupan lahan berupa kawasan hutan merupakan penutupan lahan yang dominan di Kabupaten Merangin dibandingkan dengan penutupan lahan lainnya, yaitu lahan pertanian tanaman pangan, hortikultura, perkebunan, dan lainnya. Artinya sumber daya hutan di Kabupaten Merangin sangat potensial. Dari aspek sosial-ekonomi, nilai kontribusi sub sektor kehutanan yang relatif rendah menunjukkan bahwa kawasan hutan, terutama kawasan hutan produksi, belum dikelola dengan baik sehingga belum dapat memberikan kontribusi yang optimal bagi perekonomian daerah dan kesejahteraan masyarakat.

Tabel 2. Kontribusi Lapangan Usaha/Sektor terhadap PDRB Kabupaten Merangin Tahun 2015-2017

\begin{tabular}{lllll}
\hline \multirow{2}{*}{ No } & \multirow{2}{*}{ Lapangan Usaha } & \multicolumn{3}{l}{ Kontribusi $(\%)$} \\
\cline { 3 - 5 } & & 2015 & 2016 & 2017 \\
\hline 1 & Pertanian & 49,50 & 49,35 & 49,09 \\
\hline 2 & Pertambangan dan Penggalian & 2,34 & 2,30 & 2,28 \\
\hline 3 & Industri Pengolahan & 7,79 & 7,78 & 7,76 \\
\hline 4 & Listrik dan Air Minum & 0,25 & 0,25 & 0,24 \\
\hline 5 & Bangunan & 7,29 & 7,25 & 7,25 \\
\hline 6 & Perdagangan, Hotel dan Restoran & 12,43 & 12,69 & 13,05 \\
\hline 7 & Pengangkutan dan Komunikasi & 6,18 & 6,25 & 6,40 \\
\hline 8 & Lembaga Keuangan dan Jasa Perusahaan & 4,01 & 3,91 & 3,89 \\
\hline 9 & Jasa-jasa & 10,22 & 10,23 & 10,04 \\
\hline & Jumlah & 100,00 & 100,00 & 100,00 \\
\hline
\end{tabular}

Sumber: BPS (2018), diolah 
Tabel 3. Kontribusi Sub Sektor Kehutanan terhadap PDRB Sektor Pertanian Kabupaten Merangin Tahun 2015-2017

\begin{tabular}{lllll}
\hline & Lapangan Usaha & \multicolumn{3}{l}{ Kontribusi (\%) } \\
\cline { 3 - 5 } & Tanaman Tanaman Pangan & 2015 & 2016 & 2017 \\
\hline 1 & Tanaman Hortikultura & 6,54 & 6,69 & 6,64 \\
\hline 3 & Tanaman Perkebunan & 8,07 & 8,22 & 8,43 \\
\hline 4 & Peternakan & 78,81 & 78,64 & 78,48 \\
\hline 5 & Jasa Pertanian dan Perburuan & 2,62 & 2,57 & 2,60 \\
\hline 6 & Kehutanan dan Penebangan Kayu & 0,33 & 0,33 & 0,33 \\
\hline 7 & Perikanan & 2,71 & 2,67 & 2,66 \\
\hline & Total Sektor Pertanian & 0,90 & 0,88 & 0,87 \\
\hline
\end{tabular}

Sumber: BPS (2018), diolah

Penyebab rendahnya kinerja sub sektor kehutanan jika dilihat dari nilai PDRB, antara lain karena pengelolaan kawasan hutan yang belum optimal, terutama hutan produksi yang fungsi utamanya menghasilkan hasil hutan kayu dan non kayu bagi kepentingan masyarakat, industri dan ekspor. Rendahnya produktivitas hutan produksi dikarenakan tingginya laju deforestasi dari waktu ke waktu akibat semakin meluasnya lahan terganggu, penebangan liar (illegal logging), dan penambangan liar (illegal mining) yang tidak terkendali. Berdasarkan data yang diperoleh dari [5], deforestasi tertinggi di Provinsi Jambi terjadi di Kabupaten Tebo, Kabupaten Muaro Jambi, dan Kabupaten Merangin. Dari total luas kawasan hutan produksi dan Taman Hutan Raya (Tahura) di Provinsi Jambi, deforestasi terluas terjadi di kawasan hutan produksi yaitu sebesar 94\%, sedangkan Tahura hanya 6\%. Dalam lingkup Kabupaten Merangin (Gambar 4), kawasan hutan yang telah mengalami gangguan tertinggi terjadi di hutan produksi $(66,15 \%$ dari luas hutan produksi), selanjutnya adalah hutan lindung (15,98\% dari luas hutan lindung), dan hutan konservasi (5,69\% dari luas hutan konservasi).

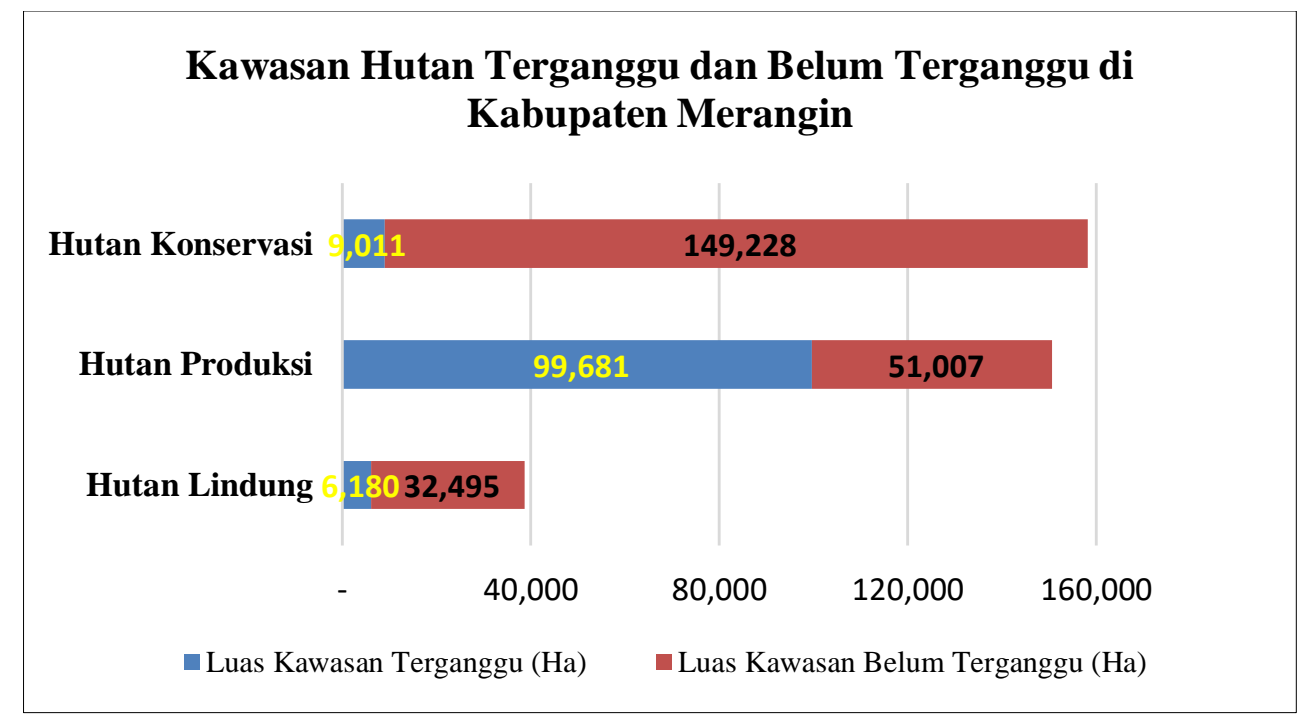

Sumber: Dinas Perkebunan dan Kehutanan Kabupaten Merangin (2018), diolah

Gambar 4. Kawasan hutan terganggu di Kabupaten Merangin

Di sisi lain, dalam perhitungan PDRB saat ini yang dikenal dengan "PDRB Coklat" juga memiliki kelemahan, di mana hanya jasa ekosistem yang bersifat terukur (tangible) saja yang dimasukkan ke dalam perhitungan PDRB, terutama produksi kayu, sedangkan jasa ekosistem lainnya yang bersifat tidak terukur (intangible), seperti ekowisata tidak dipertimbangkan. Perhitungan PDRB yang ideal sebaiknya menggunakan pendekatan "PDRB Hijau" atau juga 
dikenal dengan PDRB ramah lingkungan yang mempertimbangkan seluruh manfaat jasa ekosistem hutan produksi serta deplesi dan degradasi yang terjadi pada ekosistem hutan.

\subsection{Kebijakan dan Strategi Pengelolaan Kawasan Hutan yang Berkelanjutan}

Pengelolaan kawasan hutan di Kabupaten Merangin dihadapkan pada berbagai permasalahan dan tantangan. Identifikasi isu, peluang, dan tantangan dalam pengelolaan kawasan hutan dilakukan dengan menggunakan analisis SWOT. Identifikasi SWOT atau identifikasi kekuatan (strengths), kelemahan (weaknesses), peluang (opportunities) dan ancaman (threats) dalam pengelolaan kawasan hutan diperoleh dengan menelaah berbagai literatur dan laporan hasil penelitian terkait. Hasil identifikasi disajikan pada Tabel 4.

Tabel 4. Identifikasi kekuatan, kelemahan, peluang dan ancaman dalam pengelolaan kawasan hutan

\begin{tabular}{|c|c|}
\hline KEKUATAN (STRENGTHS): & KELEMAHAN (WEAKNESSES): \\
\hline \multirow{2}{*}{$\begin{array}{l}\text { Kondisi daya dukung berdasarkan jasa ekosistem saat ini relatif } \\
\text { baik (kategori sedang-tinggi) }\end{array}$} & Lemahnya koordinasi antar stakeholder \\
\hline & Keterbatasan SDM pengelola \\
\hline Area tutupan lahan berupa kawasan hutan relatif luas & Keterbatasan anggaran \\
\hline \multirow{2}{*}{$\begin{array}{l}\text { Adanya komitmen pemerintah pusat dan daerah serta } \\
\text { stakeholder terkait dalam mendukung pengelolaan }\end{array}$} & Keterbatasan data dan informasi dalam pengelolaan \\
\hline & Belum seluruh kawasan ditata batas dengan jelas \\
\hline Adanya dukungan kebijakan dan perundangan terkait & $\begin{array}{l}\text { Penyusunan perencanaan yang kurang tepat dan } \\
\text { pendekatannya cenderung top-down }\end{array}$ \\
\hline \multirow{3}{*}{$\begin{array}{l}\text { PELUANG (OPPORTUNITIES): } \\
\text { Potensi pendapatan bagi daerah dan masyarakat serta devisa } \\
\text { negara, terutama dari kawasan hutan produksi }\end{array}$} & ANCAMAN (THREATS): \\
\hline & Klaim lahan oleh masyarakat (konflik lahan) \\
\hline & Deforestasi/alih fungsi kawasan hutan \\
\hline \multirow[t]{2}{*}{$\begin{array}{l}\text { Dukungan internasional dalam pengelolaan hutan yang } \\
\text { berkelanjutan }\end{array}$} & $\begin{array}{l}\text { Sistem pengelolaan kawasan hutan yang cenderung } \\
\text { berorientasi pada pengeksploitasian hasil hutan berupa kayu }\end{array}$ \\
\hline & $\begin{array}{l}\text { Degradasi ekosistem hutan akibat menurunnya kualitas jasa } \\
\text { ekosistem hutan }\end{array}$ \\
\hline
\end{tabular}

Merujuk pada hasil identifikasi SWOT yang disajikan pada Tabel 4, dilakukan analisis strategi pengelolaan kawasan hutan berdasarkan: (1) kekuatan dan peluang; (2) kelemahan dan peluang; (3) kekuatan dan ancaman; dan (4) kelemahan dan ancaman. Rumusan strategi pengelolaan kawasan hutan yang berkelanjutan di Kabupaten Merangin disajikan pada Tabel 5.

Tabel 5. Rumusan Strategi berdasarkan SWOT dalam pengelolaan Kawasan Hutan yang Berkelanjutan

\begin{tabular}{|l|l|}
\hline STRATEGI (S-O) & STRATEGI (W-O) \\
$\begin{array}{l}\text { Pemanfaatan seluruh potensi jasa ekosistem yang efisien dan } \\
\text { efektif dalam upaya meningkatkan kesejahteraan masyarakat } \\
\text { dengan tetap menjaga kelestarian hutan }\end{array}$ & $\begin{array}{l}\text { Peningkatan komunikasi dan koordinasi antar stakeholder dan } \\
\text { antar sektor } \\
\text { Peningkatan kualitas SDM dalam pengelolaan kawasan hutan } \\
\text { Penetapan kebijakan pengelolaan dilakukan secara partisipatif } \\
\text { dengan melibatkan seluruh stakeholder terkait (pemerintah } \\
\text { pusat dan daerah, swasta, serta masyarakat) }\end{array}$ \\
$\begin{array}{l}\text { lembaga penelitian dan pengembangan, dan instansi lainnya. } \\
\text { Pengembangan sistem data dan informasi spasial dan non } \\
\text { spasial yang mendukung pengelolaan } \\
\text { Penerapan imbal jasa lingkungan (ekosistem) dalam } \\
\text { pengelolaan }\end{array}$ \\
\hline $\begin{array}{l}\text { STRATEGI (S-T) } \\
\begin{array}{l}\text { Penerapan kebijakan dan penegakan aturan yang berlaku } \\
\text { dalam menjaga keberadaan kawasan hutan dari deforestasi/alih } \\
\text { fungsi kawasan }\end{array}\end{array}$ & $\begin{array}{l}\text { STRATEGI (W-T) } \\
\text { Penetapan tata batas kawasan yang jelas sesuai peraturan yang } \\
\text { berlaku }\end{array}$ \\
\hline
\end{tabular}


Peningkatan peran serta masyarakat dalam perencanaan dan pengelolaan
Pemanfaatan dan pengelolaan jasa-jasa ekosistem yang seimbang dan terintegrasi

Penyusunan perencanaan yang sesuai dengan potensi dan permasalah kawasan hutan produksi dengan menggunakan pendekatan bottom-up

\section{Kesimpulan}

Prinsip kelestarian hutan diindikasikan oleh tiga fungsi pokok yang saling terkait dan tidak dapat dipisahkan antara satu dengan yang lainnya, yaitu: fungsi ekologis sebagai suatu sistem penyangga kehidupan; fungsi ekonomis sebagai sumber yang menghasilkan barang dan jasa yang terukur, seperti hasil hutan berupa kayu dan non kayu, maupun yang tidak terukur seperti ekowisata; dan fungsi sosial sebagai sumber penghidupan dan lapangan kerja serta kesempatan berusaha bagi masyarakat terutama yang hidup di sekitar hutan. Kabupaten Merangin memiliki kawasan hutan yang luas dan sangat potensial karena hasil analisis menunjukkan bahwa daya dukung kawasan hutan berdasarkan jasa ekosistem yang tersemat di dalamnya menunjukkan kondisi yang baik (termasuk dalam kategori daya dukung sedangtinggi). Jika potensi ini dapat dikelola dengan baik dan terintegrasi, maka secara ekologis keberlanjutan hutan dapat terjaga dan secara sosial-ekonomis dapat mendorong perekonomian daerah serta kesejahteraan masyarakat.

\section{Referensi}

[1] Badan Pusat Statistik (BPS) (2018) "Kabupaten Merangin dalam Angka Tahun 2018”, Badan Pusat Statistik Kabupaten Merangin, Bangko

[2] Badan Pusat Statistik (BPS) (2018) "Statistik Daerah Kabupaten Merangin 2018”, Badan Pusat Statistik Kabupaten Merangin, Bangko

[3] Millenium Ecosystem Assessment (2005) "Ecosystems and Human Well-Being: Synthesis”, Washington, D.C, Island Press

[4] Kementerian Lingkungan Hidup dan Kehutanan (KLHK) (2014) "Pedoman Penentuan Daya Dukung dan Daya Tampung Lingkungan Hidup", Jakarta

[5] Dinas Kehutanan Provinsi Jambi (2016) “Statistik Kehutanan Provinsi Jambi 2016”, Jambi 